\title{
Out of Asia: Learning re-examined, teacher education re-configured.
}

\author{
Toni Dobinson \\ Curtin University / University of Western Australia, Western Australia.
}

\begin{abstract}
The impetus for this argumentative paper is anecdotal evidence overheard in West Australian educational settings indicating that there continues to be "othering" of learners from Asian backgrounds. Exploring prevailing Western social, theoretical and educational discourses associated with Asia, the author argues that teacher education in Western Australia be reconceptualised in three main ways. Firstly, levels of metacultural sensitivity in pre-service and in-service educators should be ascertained. Secondly, there needs to be a more rigorous theoretical and conceptual framework for pre-service/in-service teacher education informed by cross cultural, historical knowledge and awareness of the social and personal constructions of reality - views of the 'other' and 'self'. Thirdly, teacher education courses must offer opportunities to examine current developments in educational research which encourage reconceptualisation and replacement of traditional East/West dichotomies. The paper aims to review literature related to theoretical Thirdness as an ontological, educational principle and to contribute to Thirdness discourse by situating the argument in a particular context in Western Australia. It is hoped that papers such as this may lead to more informed and symmetrical dialogue between educators in the Asia Pacific region.
\end{abstract}

Key words: Asian approaches to learning, Orientalism, Essentialism, metacultural sensitivity, The Third Space, teacher education.

Email: T.Dobinson@curtin.edu.au 


\section{Introduction}

Illich foreshadowed in 1970, that 'schooling' would be the New World Religion. In 2005, The United Nations Education, Scientific and Cultural Organisation (UNESCO) reported more than 2,000,000 students enrolled in tertiary institutions as foreign students (non-resident) worldwide with $52.4 \%$ from Asia - a figure just under the Asian share of world population (56.5\%) (Rosenzweig, 2008).

In Australia, the export of education to overseas students was worth $\$ 18.3$ billion in 2010 (Australian Bureau of Statistics (ABS), 2010). The top nine contributor countries were China (24.3\%), India (14.6\%), Republic of Korea (5.7\%), Malaysia (4.6\%), Vietnam (4.5\%), Thailand (3.8\%), Indonesia (3.3\%), Nepal (3.0\%) and Hong Kong (2.8\%) (AEI, 2011).

Despite the growing numbers, however, anecdotally, there still seems to be a certain opacity about the learning approaches of Asian students. Although, recent research has questioned the so-called 'Eastern' and 'Western' ways of learning (Burnett, 2005; Nakamura, 2002; Takayama, 2008), still to be heard in public space are comments such as, "This notion that they [Asians] are different to us in the way they learn... I think they definitely are" (comment from the mother of two school aged boys at the author's house). Similarly, a response to the author's decision to use focus group discussions in a piece of research provoked the following response, "That won't work with Asians... they won't speak out" while teachers have been heard to say: “They [Japanese students] don't seem to want to talk. It's a cultural thing". Such comments match those offered by Australian expatriate teachers working in Asia (Widin, 2010) and early childhood teachers in a school in Western Australia 
(Buchori, 2011) fuelling the author's suspicions that "othering" is still widespread in educational contexts in Western Australia.

The aims of the author in writing this paper, therefore, are four-fold. Firstly, the author wishes to argue the urgency of breaking down "Orientalist binary paradigms" (Takayama, 2008, p. 19) in educational institutions in Western Australia and the necessity for teacher education to be reconfigured to take into account the way that Australians and Asians have made sense of each other's approaches to learning. Secondly, the author intends the paper to critique, and provide insights into, Western discourses which have helped form the basis (either overtly or covertly) for these binary paradigms. Thirdly, the author hopes to add to existing work on Thirdness in the field (Kramsch, 2009; Lo Bianco, Liddicoat \& Crozet, 1999) by reviewing and endorsing previous writers' views on metacultural sensitivity (Louie, 2005), The Third Space (Bhaba, 1994; Kramsch, 2009), knowledge as 'culturally mediated practice' (Taylor \& Chiam, 2011, p. 9) and by situating the argument in a specific context Western Australian classrooms. Finally, the author aims to suggest practical strategies for achieving intercultural competence or Thirdness in teachers of students from Asian backgrounds.

The paper begins by considering the difficulty of defining 'culture' and what it means to be metaculturally aware in order to impress upon the reader the complexity of the issues involved. Following this, there is a discussion of related social and theoretical discourses (Orientalism, Essentialism and Postcolonialism) and subsequently, educational empirical research is unpacked in an attempt to highlight ethnocentric views of learning. The idea of Thirdness is then explored and presented as a necessity rather than an ideal for teachers in 
contact with students from diverse cultural backgrounds, and suggestions are made for how this could be achieved.

\section{"Western" social and theoretical discourses and their relation to teaching and learning in the region}

To begin arguing for greater intercultural competence in teachers, it is first necessary to examine what is meant by "culture" and to examine discourses surrounding teaching and learning. In Bordieuian terms, the word "culture" has potential symbolic violence. It has the power to define one's humanity at the expense of another's (Bordieu, 1992; Williams, 1983). Effective teachers need to develop increased metacultural sensitivity of all cultures, including their own without simply accumulating factual information or making general reductionist statements (Louie, 2005). Teachers need to tease out what they understand by Asia and Asians as well as what it means to be "Western". They need to have an awareness of the interconnected history of the two, recognising that culture is constantly "becoming" (Hall, 1990).

Metacultural understanding can start with the basics. Hofstede (2007) tells us that the distinction between Asia and Europe relates back to the Phoenicians who, while at sea, located themselves geographically between esch and ereb, East and West. Asians were "the other" part of a discourse originating with philosophical ideas from Levinas and taken up in various ways by Hegel, Lacan, De Beauvoir and Sartre, while forming the essence of a discourse called Orientalism (Abdel-Malek, 1963; Said, 1978, 1993). The name most associated with Orientalism, and central to any teacher education course preparing teachers of Asian students, is Edward Said (1935 - 2003). Said is well known for describing the Orient as 
"almost a European invention" and one of its most deep-seated and recurrent images of the "other" (1978, p. 1). He argued that the West was "able to manage - and even produce - the Orient politically, sociologically, militarily, ideologically, scientifically, and imaginatively during the post-enlightenment period" (p. 3) and used a quote from the Earl of Cromer (1908, p.146) to back up his thesis, "the Oriental generally acts, speaks and thinks in a manner exactly opposite to the European".

Travellers' narrations provided Europeans with images of the Oriental "other" that they needed in order to confirm their own self-images as Europeans (Atabaki, 2003). Accounts display "selective amnesia" in the denial of Asian ingenuity and inventiveness (TavakoliTarghi, 2001, p. 23). Asian populations are described as having "continued essentially the same" or as "unhistorical history" (Malcolm, 1815, p. 621).

Essentialist images of The Oriental have proliferated in Western social discourses over the years with artwork by Delacroix (The Women of Algiers, 1834), Spies (The Landscape and its Children, 1939), Tretchikoff (The Green Lady, 1950) and, in Australia, Dowling (A Sheik and his Son Entering Cairo..., 1874) depicting demure Asian women or timeless, Asian rural scenes. Western literature (Suzie Wong, Mason, 1957; East of Suez, Maugham, 1922; Dr Fu Man Chu, Rohmer, 1913) and, in particular, Australian "invasion fiction" (White or Yellow?, Lane, 1888; The Yellow Wave, Mackay, 1897) as well as motion pictures (Bridge on the River Kwai, 1957; Far East, 1982; Memoirs of a Geisha, 1997) have featured traditional, but sensual, women or inscrutable Asian men. More contemporary films, such as Harold and Kumar Escape from Guantanamo Bay (2008), have attempted to deconstruct contemporary stereotypes of Asian-ness but still portray the protagonists as ill-fated victims (Denison, 2009). 
Of course, critics of Said (1978) and Kabbani (1986) (for example, Tibawi, 2000; Varisco, 2007; Warraq, 2007 to name but a few) have attempted to redress the negative image of Orientalism by suggesting that, far from being a Western invention, this discourse was authorised by East Asian intellectuals in the "contact zones" (Dirlik, 1996) with, in fact, the best of Asian civilisation preserved by Western Orientalists. Nevertheless, teachers of Asian students need to be alert to Essentialist notions of "Asian culture" which focus on geography but exclude other politically and psychologically significant dimensions (Burman, 2007, p. 181). Without a basic awareness of these discourses, there can be no understanding of teaching and learning in the Asia Pacific region; no understanding of a dialogism of relationality of self and other (Bakhtin, 1981) and no appreciation of the theories of Third Space (Bhabha, 1994), a place where "third perspectives can grow in the margins of dominant ways of seeing" (Bhabha, 1994, p. 237). Teachers need to see culture as a human construct which is heterogenous (Ingleby, 2006), contradicting Essentialist views of cultural identity; a "mode" more than a permanent place to which people belong and as Kramsch says, as "imagined as it is real" (Kramsch, 2009, p. 248) suggesting a shift from "roots" to "routes" (Gilroy, 1995).

On a more positive note, discourses about Asia are changing. There is recognition that Western ideologies cannot be easily transplanted to other political or economic contexts and that Asian countries need to arrive at their own consensus about what is best for them (Mahbubani, 2008). This change is slow, however, and as Sidhu (2004, p. 51) warns, there still needs to be understandings of the "spatialities of power" as "(neo)colonial and geopolitical rationalities continue to shape 'East/West' relations". Studies which focus on the cultural dimensions of globalisation and education require articulation with political economy 
and geo-historical factors. Teacher education courses need to ensure that pre-service and inservice teachers are provided with, at least, a rudimentary understanding of the discourses above and a working knowledge of past and current empirical research in the field of education which is discussed below.

\section{Educational discourses and empirical research in the field}

An acknowledgement and investigation of educational discourses exerting influence over teachers is just as essential as scrutiny of social and theoretical discourses. Teachers of Asian students find themselves situated at the locus of postcolonial discourses as well as Western educational discourses and any teacher education course needs to recognise this. For example, mechanistic theories of learning (Knowles, 1973) associated with Behaviourism have long since been out of favour in the West with "organismic" learning being promoted (Knowles, 1973, p. 15). There is an emphasis on process over product and experience over training (Eraut, 2004; Reese \& Overton, 1970; Sun, Slusarz \& Terry, 2005). Inspired by Rogers (1969) and Maslow (1970), teachers still aim to provide opportunities for selfinitiation, discovery and self-actualisation while learner-centredness, independent learning and problem-centred thinking (Bloom, 1956; Freire, 1970; Lindeman, 1926) are seen as the corner stones of effective learning (Chan \& Kim, 2004; Tennant, 2006; Wenden, 2002).

Learning is not seen as a separate activity (Hutchins, 1970; Schön, 1983; Smith, 2001) but more as a transformation or a co-constructed understanding (Mezirow, 1991, 1994). Communication focused on meanings, values, intentions, feelings, collective or individual change and emotional and spiritual dimensions is seen as the key to learning (Boyd, 1991; Boyd \& Myers, 1988; Cunningham, 1998; Daloz, 1999; Merriam \& Caffarella, 1999; 
Mezirow, 2003) while more instrumental learning, with its pre-planned learning tasks, defined needs, behavioural objectives and acceptance of social realities defined by others, is seen as subordinate. Researchers talk about "communities of practice" (Wenger, 1998, p.5) and "situated learning" (Lave \& Wenger, 1991, p. 11). They focus on the way in which active engagement with others emulates informal apprenticeships into social communities or identities and increases access to participating roles in expert performances (legitimate peripheral participation or LPP) (Lave \& Wenger, 1991; Wenger, 1998). Workplace learning has focused on informal and experiential learning, intuitive practice and tacit knowledge (Boud \& Walker, 1990; Eraut, 2004), with learning seen as a "creative and opportunistic process emerging from contextualised interactional understandings" (Johnsson \& Boud, 2010, p. 359). Overall, there has been a paradigm shift from a view of learning as individual cognitive processes to a view of learning as a social activity inseparable from its sociocultural locus in time and space (Lave, 1988).

The promotion of these "new" directions in teaching and learning has continued across learning environments even when prevailing pedagogies have fallen outside of these hegemonies (Nozaki, 2009, p. 142). A sense of mission has been driven by research supporting teacher anecdotes that Asian students are "different" to their Western counterparts. For example, some research purports that Asian learners are more dependent on memorisation and authority and less able to think independently (Carson, 1992; Connor, 1996; Noesjirwan, 1970). Other research focuses on Asian students' lack of abstract thinking skills, reporting that they prefer to conserve knowledge rather than extend it (Atkinson, 1997; Ballard \& Clanchy, 1991, 1997; Chan, 1999; Fox, 1994). Some claim that Asian learners are constrained by issues of "face" (Chan, 1999) and display passive behaviour in the classroom (Kumaravadivelu, 2003). 
Researchers have also attempted to explain Asian learning styles to practitioners by linking classroom behaviour with cultural dimensions like individualism and collectivism, power/distance and belief systems (Basabe \& Ros, 2005; Hofstede, 1991, 2007; Phuong-Mai, Terlouw \& Pilot, 2005; Schwartz, 1999; Wintergerst, De Capua \&Verna, 2003). Some have reported research on teacher perceptions in which Asian students are seen as "almost burdened by their problem of culture" (Widin, 2010, p. 160) or with "cultural baggage" (Buchori, 2011). In particular, the idea of a Chinese culture of learning influenced by Confucian ideas has been mooted (Cheng, 2000; Kee \& Wong, 2004; Kennedy, 2002).

More recently, there has been much critique of this simplification and some questioning of what exactly is meant by culture (Tian \& Low, 2011). In particular, many have pointed out that Confucianism is multidimensional (Shi, 2006). For example, on the question of learner passivity, Confucius said, "The asking of questions is in itself the correct rite" (Confucius 3:15). Context, language ability, unfamiliarity with content and sheer inexperience at being critical (critical thinking found in ancient Chinese culture cannot be assumed to be present in contemporary Chinese culture) are much more likely to be factors affecting passivity in formal classroom environments according to some (Cheng, 2000; Goode, 2007; Gu \& Schweisfurth, 2006; Jones, 2005). Silence in any classroom is a complex topic and teacher education courses need to encourage teachers to examine the research. Harumi (2011) has highlighted the many different functions of silence, finding a mismatch between teacher and learner explanations for silence in lessons.

Another issue to be much deliberated upon by teachers of Asian students is critical thinking. This aspect of learning remains opaque in Confucius teachings with Confucius 
stating, "I transmit, but I don't innovate" (Confucius 7:1). Such quotes have provided fodder for criticism by Western educators accustomed to the so-called Socratic way of questioning, evaluating (Tweed, 2000), constructing and negotiating (Twomey Fosnot, 1989; Von Glaserfield, 1995). What is not always reported, however, is that Confucius does, in fact, urge his students to sift his teachings and criticise his statements (Confucius 11:4) provided they have enough background knowledge to do so (Confucius 7:28, 16:2, 13:3). His ideas on thinking and learning are complex. He says:

\footnotetext{
I spent all day thinking without food and all night thinking and studying without going to bed, but

I found that I gained nothing from it. It would have been better for me to have spent the time in learning. (Confucius 15:31)
}

This reference to "learning" seems to indicate memorisation and information transfer or, what has been called, a surface approach to learning (Marton \& Säljö, 1976), an approach at odds with much of Western educational philosophy. Biggs (1996) has attempted to debunk this deficit model, however, by reporting Asian students as having achieved a deep understanding of problems presented. Of course, it is probably dangerous to swing too far to the other extreme (Louie, 2005), especially as other researchers have found that course of study and year are predictors of an instrumental orientation to learning in any educational context (Azila, Sim \& Atiya, 2001; Kirkpatrick \& Mulligan, 2002; Paton, 2005); pointing out that, in reality, all students tend to adapt to whatever approach the curriculum, task or situation demands (Kember \& Gow, 1991; Rambruth \& McCormick, 2001). In addition, many researchers have now gone on to suggest that memorisation does not necessarily preclude deep understanding (Kember, 2000; Kember \& Gow, 1991). What is more, a "deep" approach to learning can take years to develop even by academics (Haggis, 2003). The premise that Asian students need to be taught to critically think in Western educational 
settings could also raise questions of the legitimacy of advocating imitative learning approaches (Kegan, 1994). As Mahbubani says, Asians need to move beyond the idea of "emulation" of the West (1998, p. 23) especially as critical thinking, in Western university settings, is sometimes little more than supervisors assessing students more highly if they mirror the lecturer's own thinking (Sandeman-Gay, 1999; Webb, 1997). What is more, critical thinking in some Asian countries can be dangerous, as an Indonesian student of the author's divulged, "we do not have the freedom to talk...a few years ago they found like a big grave where people buried there".

Western pre-occupation with learner autonomy (Chan \& Kim, 2004; Rogers, 1969; Wenden, 2002) has been contrasted with Asian teacher-centred, dependent approaches (Noesjirwan, 1970; Chan, 1999) and once again attributed to Confucianism. However, it should be noted that Confucius also said, "If one learns from others but does not think, one will be bewildered. If, on the other hand, one thinks but does not learn from others, one will be in peril" (Confucius 2:15). Large numbers in classrooms and non-negotiable curriculum have to be considered when talking about instances of learner autonomy as well as the possibility that independent learning can be facilitated eventually even with teacher-centred approaches (Brookefield, 1985a); a theory in evidence in Asian immigrants, schooled in teacher-centered ways, showing remarkable independence when forming informal networks and new businesses in new countries.

What needs to be kept in mind and conveyed in teacher education courses is, that ways of thinking and socio-political structures form a classic dialectic. Confucian attitudes, said to be characteristic of Chinese society, may be a product of the stability of the time. Other strains of Asian thought, such as Taoism and Buddhism, arose from periods of Chinese instability 
(Geyer, 2003) and recognise "disparity between the way we perceive the world and our own experience in it, and the way things actually are" (Dalai Lama, 2005, p. 46), a good basis for critical reflection and transformative thinking (Clarken, 2010). Interpretations of Confucianism have also transformed over the years with neo-Confucianists now applauding Confucian education as a path to riches and freedom (Louie, 2005), an almost heretical interpretation for traditionalists in the past. This is testimony to the fact that the truth we receive about teaching and learning is only a product of its time (Foucault, 1972), with learning often defined according to the researcher's discipline or world view (Haggis, 2003).

In short, critical pedagogy has deconstructed long-standing Orientalist binary paradigms (Takayama, 2008, p. 19) and encouraged evaluation of teaching practices within social, cultural and political contexts (Kramsch, 2009). "New" approaches to teaching and learning in teacher education courses have been accused of representing the goals and values of elite academic culture or Western educational values rather than the majority of students in a mass system (Haggis, 2003, p. 89). Therefore, there needs to be critical examination of the power and advantage often present in educational practice (Giroux, 1981) and awareness of the asymmetrical power relations manifest in our constructions of meaning (Kegan, 1994). In Bordieuian terms, there needs to be a reflective approach to the "habitus" of the players and the cultural, social, linguistic and economic capital they may possess (Bordieu, 1992). Asking Asian students to take on a new view of themselves may cause negative self-image (Johnson, 1985) and a sense of inadequacy (Aspland, 1999), with students under pressure to remodel their thinking in ways "incongruent with their very essence of being" (p. 37). They may develop images of themselves as "lacking in initiative, socially inept and boringly bookish" (Louie, 2005, p. 22). As a Bahraini Foundation Studies student confided, apologetically, to the author, "I'm from Bahrain...I can't critically think you know". 
Overall, as the literature and anecdotes portray, it is dangerous to assume that universality of theories and practice should go unquestioned (Örtenblad, Bajunid, Babur \& Kumari, 2011). It is time to move away from untenable and often dangerous binaries and embrace a new perspective as outlined below.

\section{The Third Space}

The idea of Thirdness has been taken up by researchers and writers in many fields, therefore, in order to present a convincing argument to the reader for the necessity of such thinking, the notion of Thirdness needs to be explored and elaborated upon a little more. The late 1990s saw Australian applied linguists and researchers stressing the importance of "striving for the Third Place" or intercultural competence in teachers of English as a Second language (Lo Bianco, Liddicoat \& Crozet, 1999). Kramsch then elaborated upon Bhabha's idea of the Third Space when she called for a "Third Culture or Stance" for researchers (and teachers) wanting to break down cultural dichotomies (Kramsch, 2009; Ware \& Kramsch, 2005). She maintained that teacher education should promote a "Third Culture methodology" which is sensitive to the context and adaptable to the demands of the teaching and learning environment, encouraging whatever method works in that context (2009, p. 239). She maintained that educators operating in this third space need to focus on being "plurilingual and pluricultural" with an emphasis on "the transcirculation of values...the negotiation of identities" (Zarate, Levy \& Kramsch, 2008) and an informed "conceptual repertoire of diversity" (Milner, 2010, p. 118). 
Thirdness, either as a space, a culture or a stance, sits outside Post-colonial, Orientalist and Essentialist discourses and in opposition to them and yet is defined and influenced by their very existence. Teachers of Asian students can ideally enter The Third Space on the way to becoming interculturally competent or skirt around it, with the influences of colonial discourses still very much intact and internalised (Widin, 2010). These different journeys are represented pictorially in Figure 1 given below.

FIGURE 1 HERE (see end of article)

It is apparent from what has been argued that teachers need to be given the opportunity to enter the Third Space if they are to grow as teachers and individuals and teach their Asian students effectively. Such opportunities need to arise early on in a teacher's education and continue throughout their career.

\section{Conclusions}

The author of this paper had four aims: to argue the case for teacher education courses in Western Australia to be reconceptualised to foster increased metacultural awareness in preservice and in-service teachers; to provide brief insights into Western social, theoretical and educational discourses which, the author believes, exert an influence over teaching and learning in the region; to align herself with those who believe a move towards The Third Space is long overdue (Bhaba, 1994; Kramsch, 2009; Lo Bianco, Liddicoat \& Crozet, 1999; Taylor \& Chiam, 2011) by situating the argument in a specific context - West Australian classrooms and to offer practical strategies for achieving intercultural competence or Thirdness in West Australian teachers of students from Asian backgrounds. 
So far the paper has addressed the first three aims so it just remains to attend to the fourth. Before any attention at all is given to the challenge of increasing metacultural sensitivity in teachers there needs to be qualitative research designed to ascertain the extent and depth of the influence of Western discourses (Widin, 2010, p. 106) on West Australian teachers as well as their levels of intercultural competence. Once the extent of the problem has been identified, teachers can be helped to move to where many (but not all) of their plurilingual, pluricultural, Western educated, Asian counterparts already are - The Third Space (Kramsch, 1993, 2009; Neilsen, 2011). Of course, intercultural competence does not come without some "dislocation" and "disjuncture" (Neilsen, 2011, p. 19) as one of the Vietnamese lecturers on an Applied Linguistics course offered by a West Australian university in Vietnam said: “... I am Asian but actually you know I learn, educated in the West so I bring here the Western thinking, the West ways of teaching and learning".

The Third space is not a static place either. Educational discourses are dynamic and situated and just as one idealised set of educational principles has been established, another may emerge with some countries moving towards centralised institutional pedagogic beliefs, a neo-liberal focus on testing, standards and core curriculum while others drift towards decentralisation, differentiation of curricular and a "progressive" pedagogical ethos based on humanistic notions (Takayama, 2008, p. 19). With growing numbers of Asian students studying in Australian centres of learning, Australian teachers need to be kept critically aware of such rapid global shifts in educational discourses (Takayama, 2008).

Furthermore, it is only by making all teachers aware of the social and theoretical discourses outlined briefly in this paper, that "sedimented representations" of the "self" and the "other" in teaching and learning can be broken down (Kramsch, 2009, p. 246). The 
ground for East /West dialogue has already been prepared, not only by research which has deconstructed binary paradigms (Takayama, 2008), but also by an increasing Asian confidence arising from rapid economic development in East Asia and a "realisation that their minds are not inferior" (Mahbubani, 1998, p. 23). Asians are no longer struck by "Euromania" (Al-i-Ahmed, cited in Irwin, 2008, p. 312) and as The Hon Kevin Rudd MP for Australia says, "What happens in Asia now matters not just for Asia, itself but the world" (SBS World News Australia, 2011). The current economic crisis will shake not only markets but "an entire way of thinking about how the world works" (Foroohar, 2011, p. 18). Evidence of this can be seen in the title of the latest Grattan Institute summary report, "Catching up: Learning from the best school systems in East Asia" (Jensen, 2012).

Teacher education courses need to foster greater "metacultural sensitivity" (Louie, 2005, p. 17) by providing university or school wide units of learning which explore changing social, political, historical, cultural landscapes and world views, as well as the construction of the "self" and "others". Added to this should be opportunities to examine current developments in educational research which can provide "a conceptual lens" to help replace outmoded dichotomies (Kramsch, 2009, p. 248) by altering ways of thinking (Milner, 2010). Thus armed, teachers would be in a stronger position to be able to conduct interdisciplinary, qualitative research which is mindful of the social and political ramifications of education and culturally situated ethnocentric meaning constructions. Without such opportunities, teachers may desist from questioning power structures, operating solely from their own cultural references, ways of knowing and experiences (Milner, 2010).

With transnational education on the increase, the joint delivery of courses by host and home country lecturers is also the first step towards dialogue between educators from 
different cultural backgrounds. Equipped with greater intercultural competence, educators in the Asia Pacific region could think outside of national borders and arrive at a view of learning which goes beyond Orientalist binary paradigms (Takayama, 2008, p. 19) facilitating more symmetrical dialogue between Asian teachers and Australian teachers and enabling teachers to maximise learning opportunities with Asian learners in their classrooms. As Hamston (2000, p. 66) says, "our values and our ways of seeing the world ... are never complete, finished; each individual's 'becomingness' is open and dialogue keeps this process alive”.

\section{Acknowledgements}

Thank you to all the reviewers and the editors who gave so willingly of their time in order to provide me with guidance and feedback.

\section{References}

Abdel-Malek, A. (1963). Orientalism in crisis. Diogenes, 44, 104-112.

Aspland, T. (1999). 'You learn round and I learn square': Mei’s story. In Y. Ryan \& O. Zuber-Skerritt (Eds.), Supervising postgraduates from non-English speaking backgrounds (pp.25-39). Buckingham: Open University Press.

Atabaki, T. (2003). Beyond Essentialism: Who writes whose past in the Middle East and Central Asia? Amsterdam: Amersfoort.

Atkinson, D. (1997). A critical approach to critical thinking in TESOL. TESOL Quarterly, 31(1), 71-94.

Australian Bureau of Statistics. (2010). Retrieved from

http://www.abs.gov.au/AUSSTATS/abs@.nsf/web+pages/statistics

Australian Education International (AEI) (2011). Transnational education in the higher education sector. Retrieved from http://www.aei.gov.au/research/Research-Snapshots/Documents

Azila, N. M., Sim, S. M., \& Atiya, A. S. (2001). Encouraging learning how to fish: An uphill but worthwhile battle. Annals of the Academy of Medicine Singapore, 30(4), 375-378. 
Bakhtin, M. (1981). The dialogic imagination: Four essays. Austin: University of Texas Press.

Ballard, B., \& Clanchy, J. (1991). Teaching students from overseas. Cheshire: Longman.

Ballard, B., \& Clanchy, J. (1997). Teaching international students. Deakin: IDP Australia.

Basabe, N., \& Ros, M. (2005). Cultural dimensions and social behavior correlates: Individualism- collectivism and power distance. Revue Internationale de Psychologie Sociale, 18(1), 189-225.

Bhabha, H. (1994). The location of culture. London: Routledge.

Biggs, J. (1996). Western mis-perceptions of the Confucian - heritage learning culture. In D. Watkins \& J. Biggs (Eds.), The Chinese learner: Cultural, psychological and contextual influences (pp. 45-67). Hong Kong: Comparative Education Research Centre and Melbourne: The Australian Council for Educational Research.

Bloom, B. S. (Ed.). (1956). Taxonomy of educational objectives: Book 1 cognitive domain. London: Longman.

Bordieu, P. (1992). Thinking about limits. Theory, Culture and Society, 9, 37-49.

Boud, D., \& Walker, D. (1990). Making the most of experience. Studies in Continuing Education, 12(2), 61-80.

Boyd, R. D. (1991) (Ed.). Personal transformations in small groups: A Jungian perspective. London: Routledge.

Boyd, R., \& Myers, J. G. (1988). Transformative education. International Journal of Lifelong Education, 7(4), 261-284.

Brookefield, S. (1985a). Self-directed learning: A critical review of research. In S. Brookefield (Ed.), Self directed learning: From theory to practice (pp. 5-16). San Francisco: Jossey-Bass.

Buchori, S. (2011). Educators' perspectives of cultural diversity and teaching and learning in multicultural early childhood settings. Honours Thesis. Curtin University.

Burman, E. (2007). Between Orientalism and normalization: Cross-cultural lessons from Japan for a critical history of psychology. History of Psychology, 10(2), 179-198.

Burnett, G. (2005). Language games and schooling: Discourses of colonialism in Kiribati education. Asia Pacific Journal of Education, 25(1), 93-106.

Carson, J. (1992). Becoming biliterate: First language influences. Journal of Second Language Writing, 1(1), $37-60$.

Chan, S. (1999). The Chinese learner - a question of style. Education and Training, 41(6/7), 294-304.

Chan W. M., \& Kim, D. H. (2004). Towards greater individualization and process-oriented learning through electronic self-access: Project “e-daf”. Computer Assisted Language Learning 17(1) 83-108.

Cheng, X. (2000). Asian students' reticence revisited. System, 28, 435-446. 
Clarken, R. (2010). Socratic knowledge, Christian love, Confucian virtue, and Buddhist emptiness: Guiding principles for education. Paper presented at the 2010 Michigan Academy of Science, Arts \& Letters Conference, Calvin College, Grand Rapids, MI. Retrieved from www.eric.ed.gov/PDFS/ED509642.pdf Confucius the analects.(1979). Middlesex, England: Penguin.

Conner, U. (1996). Cross cultural aspects of second language writing. Cambridge: CUP.

Cromer, Earl of (1908). Modern Egypt. London: The Macmillan Company.

Cunningham, P. (1998). The social dimension of transformative learning. PAACE Journal of Lifelong Learning, 7, $15-28$.

Dalai Lama. (2005). The universe in a single atom. New York: Doubleday Broadway.

Daloz, L. (1999). Mentor: Guiding the journey of adult learners. San Francisco, CA: Jossey-Bass.

Delacroix, E. (1834). The women of Algiers [Painting]. Louvre, Paris.

Denison, R. (2009). Australia: Orientalism, whiteness, and the transnational Hollywood blockbuster. Retrieved from http://www.puremovies.co.uk/articles/australia.orientalism-whiteness-and-the-transnationalhollywood-blockbuster

Dirlik, A. (1996). Chinese history and the question of Orientalism. History and Theory, 35(4), 96-118.

Dowling, R. (1874). A sheik and his son entering Cairo, on their return from a pilgrimage to Mecca [Painting]. National Gallery of Victoria, Melbourne.

Eraut, M. (2004). Informal learning in the workplace. Studies in Continuing Education, 26(2), 247-273.

Foroohar, R. (2011). The end of Europe. Time 178(7), 17-21.

Foucault, M. (1972). The archeology of knowledge and the discourse on language. New York: Tavistock.

Fox, H. (1994). Listening to the world. Urbana, IL: National Council of Teachers of English.

Freire, P. (1970). Pedagogy of the oppressed. USA: Herder \& Herder.

Geyer, R. (2003 September 19). Europeanisation, complexity, and the British welfare state. Paper presented at the UACES/ESRC Study Group on The Europeanisation of British Politics and Policy-Making, Department of Politics, University of Sheffield, UK.

Gilroy, P. (1995). Roots and routes: black identity as an outernational project. In H. W. Harris, H. C. Blue \& E. E. H. Griffith (Eds.), Racial and Ethnic Identity: Psychological Development and Creative Expression (pp. 15-30). New York: Routledge.

Giroux, H. A. (1981). Ideology, culture and the process of schooling. London: Falmer Press.

Golden, A. (1997). Memoirs of a geisha. USA: Knopf. 
Goode, J. (2007). Empowering or disempowering the international PhD student? Constructions of the dependent and independent learner. British Journal of Sociology of Education, 28(5), 589-603.

Gu, Q., \& Schweisfurth, M. (2006). Who adapts? Beyond cultural models of 'the' Chinese learner. Language Culture and Curriculum,19(1), 74-89.

Haggis, T. (2003). Constructing images of ourselves? A critical investigation into 'approaches to learning' research in higher education. British Educational Research Journal, 29(1), 89-104.

Hall, S. (1990). Cultural identity and diaspora. In J. Rutherford (Ed.), Identity, community, difference (pp. 222237). London: Lawrence and Wishart.

Hamston, J. (2000). 'Reading' Asia: Selective traditions, talking futures. Viewpoints on Literacy: Challenging Voices, Changing Views, 63-67.

Harumi, S. (2011). Classroom silence: Voices from Japanese EFL learners. ELT Journal, 65(3), 260-269.

Hofstede, G. (1991). Cultures and organizations: Software of the mind. London: McGraw-Hill.

Hofstede, G. (2007). Asian management in the $21^{\text {st }}$ century. Asia Pacific Journal of Management, 24, 411-420.

Hutchins, R. M. (1970). The learning society. Harmondsworth: Penguin.

Illich, I. (1970). Deschooling society. Harmondsworth, Middlesex: Penguin.

Ingleby, J. (2006). Hybridity or the third space and how shall we describe the kingdom of God? Retrieved from www.redcliffe.org/mission.

Irwin, R. (2006). Dangerous knowledge. Woodstock: The Overlook Press.

Jensen, B. (2012). Catching up: Learning form the best school systems in East Asia. Retrieved from apo.org.au/research

Johnson, F. (1985). The western concept of self. In A. J. Marsella, G. De Vos, \& F. L. K. Hsu (Eds.), Culture and self: Asian and western perspectives (pp. 91-137). New York: Tavistock Publications.

Johnson, M. C., \& Boud, D. (2010). Towards an emergent view of learning work. Journal of Lifelong Education, 29(3), 359-372.

Jones, A. (2005). Culture and context: Critical thinking and student learning in introductory macro-economics. Studies in Higher Education, 30(3), 339-354.

Kabbani, R. (1986). Europe's myths of Orient. London: MacMillan Press.

Kee, J., \& Wong, K. (2004). Are the learning styles of Asian international students culturally or contextually based? International Education Journal, 4(4), 1-17. 
Kegan, R. (1994). In over our heads: The mental demands of modern life. Massachusetts: Harvard University Press.

Kember, D. (2000). Misconceptions about the learning approaches, motivation and study practices of Asian students. Higher Education, 40, 99-121.

Kember, D., \& Gow, L. (1991). A challenge to the anecdotal stereotype of the Asian student. Studies in Higher Education, 16(2), 117-128.

Kennedy, P. (2002). Learning cultures and learning styles: Myth-understandings about adult (Hong Kong) Chinese learners. Journal of Lifelong Education, 21(5), 430-445.

Kirkpatrick, A., \& Mulligan, D. (2002). Cultures of learning: Critical reading in the social and applied sciences. Australian Review of Applied Linguistics, 25(2), 73-99.

Knowles, M. (1973). The adult learner: A neglected species. Houston: Gulf Publishing.

Kramsch, C. (2009). Third culture and language education. Retrieved from www.irc.cornell.edu/events/past/2008-2009/papers08/third/p.d.f

Kumaravadivelu, B. (2003). A postmethod perspective on English language teaching. World Englishes 22(4), 539-550.

Lane, W. (1888). White or yellow? The Boomerang, 10.3.1888; 18.2.1888.

Lave, J. (1988). Cognition in practice: Mind, mathematics and culture in everyday life. Cambridge: CUP.

Lave, J., \& Wenger, E. (1991). Situated learning: Legitimate peripheral participation. Cambridge: CUP.

Lindeman, E.C. (1926). The meaning of adult education. New York: New Republic.

Lo Bianco, J., Liddicoat, A. J., \& Crozet, C. (Eds.). (1999). Striving for the Third Place: Intercultural competence through language education. Melbourne: Language Australia.

Louie, K. (2005). Gathering cultural knowledge: Useful or use with care? In J. Carroll \& J. Ryan (Eds.), Teaching international students: Improving learning for all (pp. 17-25). London: Routledge.

Mackay, K. (1897). The yellow wave. London: R. Bentley.

Mahbubani, K. (1998). Can Asians think? Singapore: Times Books International.

Mahbubani, K. (2008). The new Asian hemisphere: The irresistible shift of global power to the east. New York: Public Affairs.

Malcolm, J. (1815). The history of Persia from the most early period to the present time. London: John Murrray. 
Marton, F., \& Saljo, R. (1976). On qualitative differences in learning. 1_Outcome and process, British Journal of Educational Psychology, 46, 4-11.

Maslow, A. H. (1970). Motivation and personality. New York: Harper \& Row.

Mason, R. (1957). Suzie Wong. UK: Collins.

Mason, R. (Producer), \& Duigan, J. (Director). (1982). Far East [Motion picture]. Australia: Village Roadshow.

Maugham, S. (1922). East of Suez. A Play in Seven Scenes. New York: George H. Doran Company.

Merriam, S. B., \& Caffarella, R. S. (1999). Learning in adulthood: A comprehensive guide. 2nd Ed. San Francisco, CA: Josssey-Bass.

Mezirow, J. (1991). Transformative dimensions of adult learning. San Francisco, CA: Jossey-Bass.

Mezirow, J. (1994). Understanding transformation theory. Adult Education Quarterly, 44(4), 222-233.

Mezirow, J. (2003). Transformative learning as discourse. Journal of Transformative Education, 1(1), 58-63.

Milner, R. (2010). What does teacher education have to do with teaching? Implications for diversity studies. Journal of Teacher Education, 61(1-2), 118-131.

Nakamura, K. (2002). Cultivating global literacy though English as an International Language (EIL) education in Japan: A new paradigm for global education. International Educational Journal, 3(5), 6474.

Neilsen, R. (2011). Moments of disruption' and the development of expatriate TESOL teachers. EA Journal, $27(1), 17-31$.

Noesjirwan, J. (1970). Attitudes to the Asian student studying in the West. Journal of Cross-Cultural Psychology, 1, 393-397.

Nozaki, Y. (2009). Critical teaching about Asia: Orientalism, postcolonial perspectives and cross-cultural education. Journal of Intercultural Studies, 30(2), 141-155.

Örtenblad, A., Bajunid, I. A., Babur, M., \& Kumari, R. (Eds.). (2011). Are theories universal? Malaysia: ELLTA \& Yayasan Ilmuwan.

Paton, M. (2005). Is critical analysis foreign to Chinese students? In E. Manalo \& G. Wong-Toi (Eds.), Communication skills in university education: The international dimension (pp. 1-11). Auckland: Pearson Education.

Phuong-Mai, N., Terlouw, C., \& Pilot, A. (2005) Cooperative learning vs Confucian heritage culture's collectivism: confrontation to reveal some cultural conflicts and mismatches. Asia Europe Journal, 3, 403419. 
Ramburuth, P., \& McCormick, J. (2001). Learning diversity in higher education: A comparative study of Asian international and Australian students. Higher Education,42, 333-350.

Reese, H. W., \& Overton, W. F. (1970). Models of development and theories of development. In L. R. Goulet \& P. B. Baltes (Eds.), Life-span developmental psychology (pp. 115-145). New York: Academic Press.

Rogers, C. R. (1969). Freedom to learn. Ohio: Bell \& Howell.

Rohmer, S. (1913). The mystery of Dr. Fu-Manchu. London: Methuen.

Rosenzweig, M. R. (2008). Higher Education and international migration in Asia: Brain circulation. In J. Y. Lin \& B. Pleskovic (Eds.), Annual World Bank conference on developing economics 2008: Regional: Higher education and development part 489. (pp. 59-84), Washington: World Bank Publications.

Said, E. W. (1978). Orientalism. London: Penguin.

Said, E. (1993). Culture and imperialism. London: Chatto \& Windus.

Sandeman- Gay, E. (1999). Supervising Iranian students: A case study. In Y. Ryan \& O. Zuber-Skerritt (Eds.), Supervising postgraduates from non-English speaking backgrounds (pp. 40-47). Buckingham: Open University Press.

SBS World News Australia (2011). Rudd backs 'negotiated' two state solution. Retrieved from $\underline{\text { www.sbs.com.au/news/asia-pacific }}$

Schön, D. (1983). The reflective practitioner: how professionals think in action. New York: Basic Books.

Schwartz, S. (1999). A theory of cultural values and some implications for work. Applied Psychology: An International Review, 48(1), 23-47.

Shapiro, G. (Producer), Hurwitz, J., \& Schlossberg, H.(Directors). (2008). Harold and Kumar escape from Guantanamo Bay. [Motion picture]. USA: Warner Bros.

Shi, L. (2006). The successors to Confucianism or a new generation? A questionnaire study on Chinese students' culture of learning English. Language, Culture and Curriculum, 19(1), 122-139.

Sidhu, R. (2004). Governing international education in Australia. Globalisation, Societies and Education, 2(1), 1-33.

Smith, M. (2001). Donald Schön: Learning, reflection and change. The Encyclopedia of Informal Education. Rretrieved August 18, 2011, from http://www.infed.org/thinkers/et-schon.htm

Speigel,S. (Producer), \& Lean, D. (Director). (1957). The bridge on the River Kwai [motion picture]. UK: Colombia Pictures.

Spies, W. (1939). The landscape and its children [Painting]. Agung Rai Gallery, Bali. 
Sun, R., Slusarz, P., \& Terry, C. (2005). The interaction of the explicit and the implicit in skill learning: A dual-process approach. Psychological Review, 12(1), 159-192.

Takayama, K. (2008). Beyond Orientalism in comparative education: challenging the binary opposition between Japanese and American education. Asia Pacific Journal of Education, 28(1), 19-34.

Tavakoli-Targhi, M. (2001). Refashioning Iran: Orientalism, occidentalism and historiography. St Antony's, New York: Palgrave.

Taylor, P. G., \& Chiam, C. L. (2011). Theories and epistemic positions - Universal, personal and cultural possibilities. In A. Örtenblad, I.A. Bajunid, M. Babur \& R. Kumari (Eds.), Are theories universal? (pp. 717). Malaysia: ELLTA \& Yayasan Ilmuwan.

Tennant, M. (2006). Psychology and adult learning. Abingden, Oxon: Routledge.

Tian, J., \& Low, G. (2011). Critical thinking and Chinese university students: A review of the evidence. Language, Culture and Curriculum, 24(1), 61-76.

Tibawi, A. L. (2000). A second critique of English-speaking Orientalists. In A. L. Macfie (Ed.), Orientalism: A reader. (pp. 208-216). New York: New York University Press.

Tretchikoff, V. (1950). The green lady [Painting] Cape Town National Gallery, Capetown.

Tweed, R. G. (2000). Learning considered within a cultural context: Confucian and Socratic approaches. PhD Thesis. The University of Colombia.

Twomey Fosnot, C. (1989). Enquiring teachers, enquiring learners: A constructivist approach for teaching. New York: Teachers' College Press.

Varisco, D. M. (2007). Reading Orientalism: Said and the unsaid. Seattle: University of Washington Press.

Von Glaserfield, E. (1995). A constructivist approach to teaching. In L. P. Steffe \& J. Gale (Eds.), Constructivism in education (pp. 3-16). New Jersey: Lawrence Erlbaum Assoc.

Warraq, I. (2007). Defending the West. New York: Prometheus Books.

Ware, P., \& Kramsch, C. (2005). Toward an intercultural stance: Teaching German and English through telecollaboration. The Modern Language Journal, 89(2), 190-205.

Webb, G. (1997). Deconstructing deep and surface approaches towards a critique of phenomenography. Higher Education, 33(2), 195-212.

Wenden, A. L. (2002). Learner development in language learning. Applied Linguistics, 23 (1): 32-55.

Wenger, E. (1998). Communities of practice: learning, meaning and identity. Cambridge: CUP.

Widin, J. (2010). Illegitimate practices: Global English language education. Bristol, UK: Multilingual Matters. 
Williams, R. (1983). Keywords. New York: OUP.

Wintergerst, A. C., DeCapua, A., \& Verna, M. A. (2003). Conceptualising learning style modalities for ESL/EFL students. System, 31, 85-106.

Zarate, G., Levy, D., \& Kramsch, C. (Eds.). (2008). Presis du plurilinguisme et du pluriculturalisme. Paris: Editions des Archives Contemporaries.

\section{Bio-data:}

Toni Dobinson is a lecturer at Curtin University, Western Australia. This paper has arisen from work done in Ho Chi Min City, Vietnam and a PhD study being conducted through the University of Western Australia entitled: Encountering the 'Asian learner': teaching and learning experiences of postgraduate Asian learners and their lecturers in Western Australia and Vietnam. 


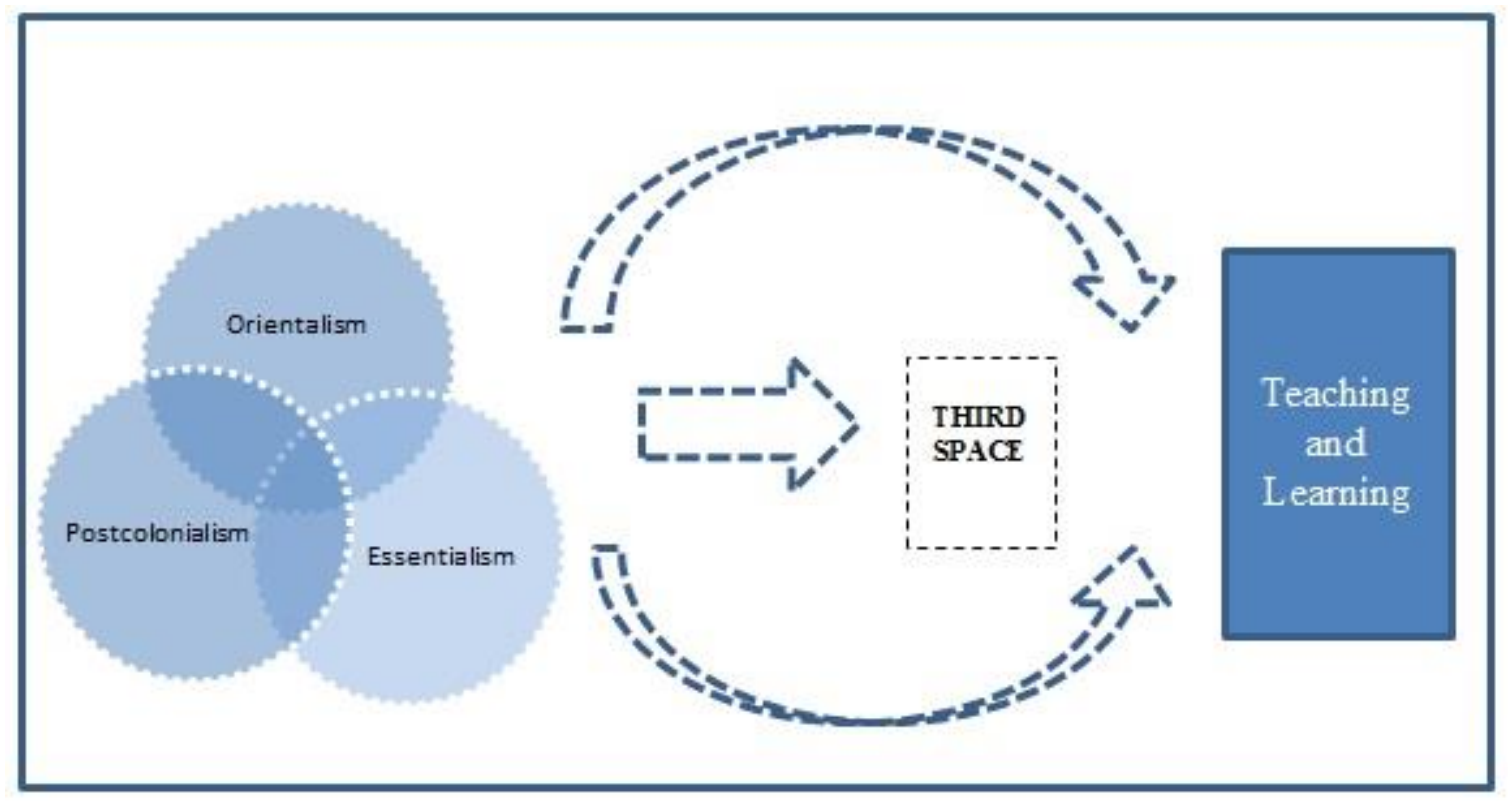

Figure 1: Movement from Postcolonial, Orientalist and Essentialist discourses through or around The Third Space to teaching and learning 